\title{
AN INVESTIGATION OF THE SILHOUETTES OF CHRISTIAN DIOR
}

\author{
Krasimira Radieva \\ Faculty of Technics and Technologies, Trakia University, Bulgaria \\ Graf Ignatiev 38, 8600 Yambol, Bulgaria, e-mail: krasiradieva@abv.bg
}

\begin{abstract}
The variety of silhouettes is one of main features of Christian Dior's creativity. The aim of presented paper is a study and analysis of the silhouettes of Christian Dior for determination of connection between a silhouette and the body form and presentation of a silhouette with simple geometric forms. The silhouettes of Christian Dior in his couture collections in the period between 1947 and 1957 are studied, analysed and approximated with combination of well-known simple geometric forms - curved forms of ellipses, ovals, circles, full figures or their parts, and straight ones of rectangles and trapeziums. The investigation of the silhouettes with the application of approximation with well-known simple geometric forms helps the students in their studies in fashion. The approximated geometric approach helps the activity of fashion designers and pattern makers in their creations of new silhouette forms and their proportions to the human body.

Keywords: Christian Dior, fashion design, silhouette, approximation.
\end{abstract}

\section{INTRODUCTION}

There are so many basic design principles in the fashion industry: the choice and interpretation of the form, the silhouette, lines, construction, structure, and fabrics. The form of one garment has main sign in the processes of design and pattern making. The designer at first decides which the form of a cloth will be and after that he or she considers how it has to be constructed. The choice of a silhouette depends on the fashion trends and determines which parts of the body have to be emphasised, and volumes, proportions and materials. The silhouette is the contour of costume and creates the first its impression before forms of pieces and elements, fabrics and colors of garments. In the contemporary fashionable world, in concurrent environment the fashion producers invest a lot of time, means and energy for creation of their brands' silhouettes, which attract consumers.

The variety of silhouettes is one of main features of Christian Dior's creativity.

The aim of presented paper is a study and analysis of the silhouettes of Christian Dior for determination of connection between a silhouette and the body form and presentation or approximation of a silhouette with simple geometric forms.

\section{SILHOUETTES OF CHRISTIAN DIOR IN HIS COUTURE COLLECTIONS IN THE PERIOD BETWEEN 1947 AND 1957}

The silhouettes in Couture collections of Christian Dior are investigated in the sequence of their creation. A sequence is presented in graphic way in Figure 1. [1]

The approximation of the silhouette or the part of silhouette to one or another simple geometric form is considered as a tool in the designer's work on the costume composition. In the costume analysis the geometry gives a possibility of an investigation of the law of creation of costume forms as the geometry of the human body form are studied by canons of their constructions. [2]

The 20 century finally confirms the basic requirements for the suit: suitability, comfort, practicality. In the same way the basic aesthetic principle is the maximal artistic IRTIIE Vol. 7, No. 3, 2019 ISSN 1314-8788 (print), ISSN 1314-8796 (online), doi: 10.15547/artte.2019.03.002 


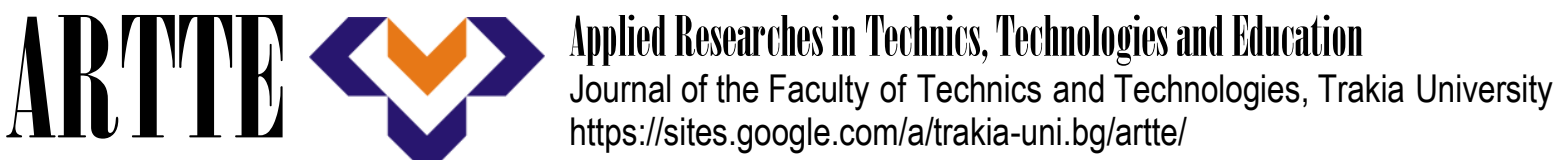

expressiveness, which is created with minimal artistic tools, and the identification of individuality in the mass production costume. The fashion designers' creative search is directed to complicated colors, proportions and silhouettes of costume, to ensemble creation for rational wardrobe and substitutability of its elements, and creation of clothing, which are suitable to different types of human activities. [3]

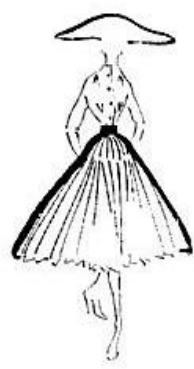

SPRING 1N7

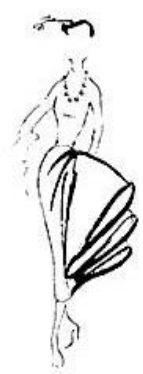

SPRING 1945

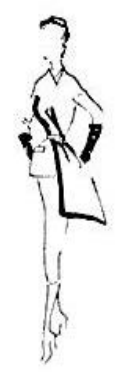

AUTUMN 1950

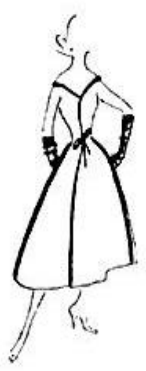

$\underset{\substack{\text { AUTuss } \\ \text { Compontion ion }}}{1953}$

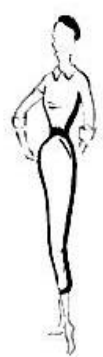

AUTUMN 198)

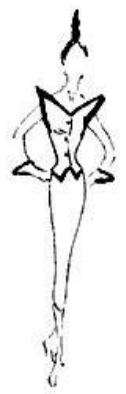

SFRING 1999

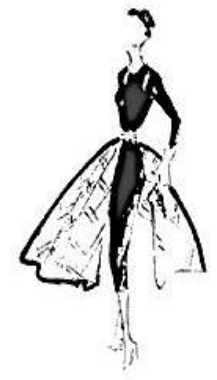

SPRNG IIS9

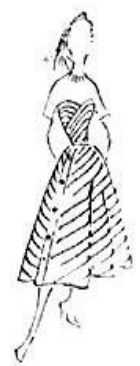

AUTUMN 1950

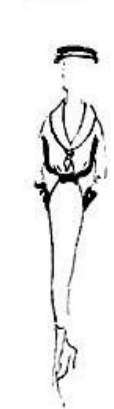

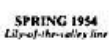

AUTUMN 1947

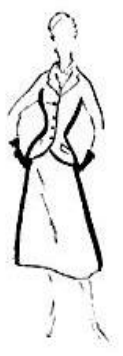

SPRING 1951

$\underset{\text { AUTum }}{1954}$
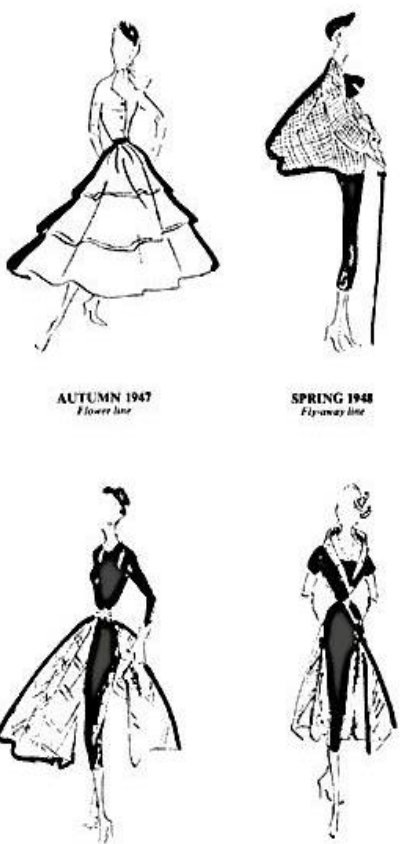

AUTUMN 199
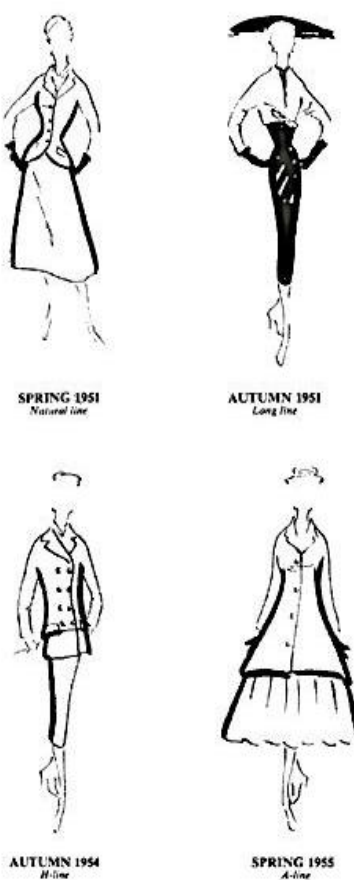
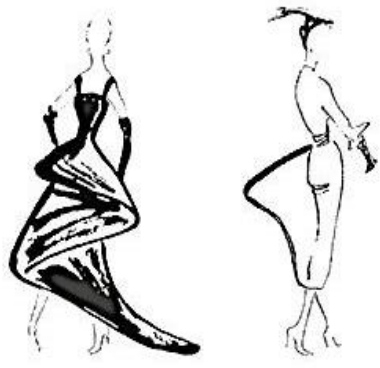

AUTUMN 1948

AUTUMN 1948

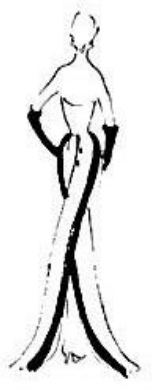

AlTUMN 1949

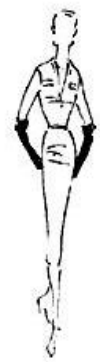

SPRING 1950
Vericed ins
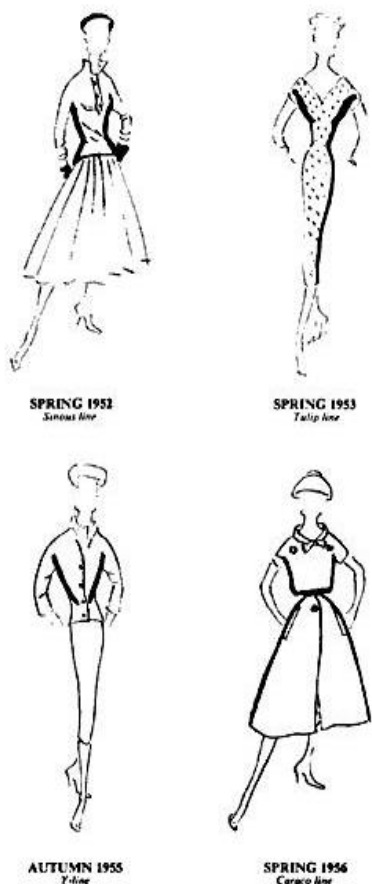

Figure 1. Dior lines (silhouettes) illustration 1957. Victoria and Albert Museum, London [1] IRTIIE Vol. 7, No. 3, 2019 ISSN 1314-8788 (print), ISSN 1314-8796 (online), doi: 10.15547/artte.2019.03.002 


\section{ARTTE $Y$}

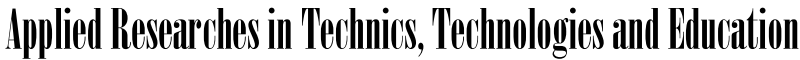

Journal of the Faculty of Technics and Technologies, Trakia University https://sites.google.com/a/trakia-uni.bg/artte/

By 1950 Christian Dior was the most famous fashion designer in the world. Vogue wrote that year, "Dior is the dynamic meteoric showman of the Couture. In all his collections, there is something of the sensational, and - importantly - something that is sure to forecast a trend." (Paris Directory: Names in the News," Vogue, March 1, 1950, p. 5). [4]

From the launch to his death 10 years later, Christian Dior designed 22 collections, each comprising over 90 looks. The names he chose for each new line reflected the dominant silhouette, from Zig-zag, Verticale and Sinueuse to more concrete suggestions of Tulipe, Fleche ("arrow") and Fuseau ("spindle"). [5]

\section{THE NEW LOOK}

Christian Dior's name for his first Collection was quiet and unassuming: he called it, simply, the Corolle line because of the flower-like way the huge skirts blossomed out from slender, stem-like waists.

Dior's Corolle line, the New Look, was the exact opposite of what women had been wearing for the last seven years. Here were skirts that used up to 15-even 25-yards of material and reached down nearly to the ankles. Waists were nipped-in and tiny, often with a shaped leather belt. Bodices were neat and close-fitting and emphasized rounded breasts. The crude square pads had gone from the shoulders, and hips were made fuller with pleats or pads instead. Jackets had pinched-in waists too, with peplums that flared out to emphasize the hips; and even the straight skirts Dior showed were feminine and flattering and bore no resemblance to the boxy wartime kind. Pleats whirled, silks rustled, petticoats peeped and the audience became ecstatic.

Dior's second Collection, shown in July 1947, was the New Look again 'pushed to extremes,' he said. Dresses were even longer and skirts took up even more material. [6]

Hemlines were dropped to twelve inches from the floor, even lower than Balenciaga had attempted the previous year. The tiny waist was applied to virtually every mode, reversing the long-standing fashion freedom initiated by Poiret and expanded upon by Chanel two decades earlier. [7]

\section{ENVOL AND ZIG-ZAG}

With collections called "Envol" and "Zig Zag", Dior's 1948 couture experimented with ideas of flight and movement. Clothes were given energy and lightness by means of asymmetrical, swooping hemlines, thrusting bustles, and torque collars that reached up and away from the neckline. The basic New Look shape - the tiny waist, soft shoulder, long length - remained but, as Vogue wrote, "skirts focusing entirely on back interest" were the order of the day. This derriere de Paris featured gathered or stiffened fabric that appeared to bloom straight from the small of the back, beneath which skirts were full, and built on padded foundation, or slim and straight. Peplums gave a less exaggerated nod to the trend, as did a dress with buttons marching up the back. [8]

Skirts, still long of course, were given lots of movement by scooping them up at one side or, bustle-like, at the back, or simply by pushing all the fullness towards what Vogue coyly called the 'derriere'. The new, short jacket with its loose, fly-away back proved to be popular, as did the introduction of dramatic, stand-up collars. Giant cuffs, added to some jackets, were described by Vogue as 'flapping like seal fins'.

Zig-Zag was the name given to the Autumn Collection, its aim being to 'give the figure the animated look of a drawing'. Its hallmarks were the curious asymmetrical - or, if you like, zigzag - necklines given to evening dresses. There were one-shoulder dresses, one-sleeve dresses and a complicated system of draping and wrapping bodices to produce a neckline that went off at a tangent. A much simpler idea was the introduction of long, tight sleeves on

IRTIIE Vol. 7, No. 3, 2019 ISSN 1314-8788 (print), ISSN 1314-8796 (online), doi: 10.15547/artte.2019.03.002 


\section{ART'TlE $Y^{2}$}

Ipplied Resseirlores in Technics, Technologies and Bductation

Journal of the Faculty of Technics and Technologies, Trakia University https://sites.google.com/a/trakia-uni.bg/artte/

cocktail and dinner dresses. Skirts were given uneven, zig-zag hemlines to make them fit in to the zig-zag theme.

Vogue summed it all up after the Autumn shows: "Most of the Collection news is detail. A skirt-length, a cuff, a neckline is suddenly more important than any one silhouette." [6]

\section{TROMPE L'OEIL AND MID-CENTURY}

1949's "Trompe L'Oeil" and "Mid-Century" Collections continued with Dior's interest in line, as well as surface detail, reinforcing his basic ideas. Pockets abounded, adding volume to a tight, slim skirt or molded bodice, making an outsized design gesture on a pleated skirt. Tube skirts were, Vogue reported, "so narrow they must be slit for walking." [8]

In his Trompe l'oeil Collection, Dior used all sorts of tricks to make busts look wider: huge revers jutted out on either side like wings, giant collars over-lapped the shoulders, pockets were placed high on the bodice or on the bust itself. But for evening there was a much more straightforward way of emphasizing the bosom - Dior simply made his dresses barer and barer. There were wide sweeping decolletés, daring plunge necklines and lots of strapless dresses.

To achieve the important feeling of movement without heaviness or bulk, he put flying panels or pleats on nearly every skirt; when standing still the figure looked slender and lean, but with movement the panels fluttered and flew.

Dior's Autumn Collection was called the Mid-century look. The new Dior dresses and suits were softly bloused on top with tiny belted waists and pencil skirts so narrow they clearly needed the famous 'Dior Pleat' (a slit backed with a panel of fabric) so that the girls could walk. There were dresses with full skirts too, but these were flowing and easy, and not padded crinolines of the New Look.

That season's bloused and belted jackets and bodices were very different to the neat-fitting New Look ones, but the look was easy and full of vitality. Vogue said his dresses looked like 'first cousins' to the American shirtwaister. Evening dresses were slick and sexy and very worldly; they were usually short, often strapless and nearly always pencil slim. Dior invented a new skirt for them - the Scissor skirt - which had two 'blades' of fabric over a slender underskirt. [6]

\section{VERTICAL AND OBLIQUE LINE}

The first new look of the fifties was Dior's Vertical Line. Unlike the narrow, boxy silhouette of the L-85 styles from World War II, the Dior Vertical Line Collection maintained the emphasis on femininity that the designer had initiated with his fitted and shaped New Look. In addition to narrowed lines, the style featured horseshoe collars, draped aprons, cutaway box jackets, and crystal-pleated skirt. Of all the new silhouettes in the collection, asserted Vogue, the "most important single day fashion [was] the straightline sheath." (Ibid., "Paris Tendencies," March 1, 1950, 124). [7]

The Vertical line was not one of Dior's historic Collections, but nevertheless it was packed with ideas and was widely copied. Vertical line clothes were for spring and summer, and, logically, dresses were more often sleeveless - helping to create the look of a straight line between shoulder and hip that Dior was aiming at. Dior's Vertical line also meant new, straight boxy jackets in all lengths, and loose duster coats. He invented two new collar shapes to emphasize the Vertical line: enormously long revers that plunged down almost to the waist, or a curved version of the same thing that was known as the horseshoe collar, and was widely copied.

Dior stayed with geometry for his Autumn Collection, which he named the Oblique line. There were reappearances of the asymmetrical necklines and bodices he had loved in previous

IRTIIE Vol. 7, No. 3, 2019 ISSN 1314-8788 (print), ISSN 1314-8796 (online), doi: 10.15547/artte.2019.03.002 


\section{ART'THE}

Ipplied Resseirlores in Technics, Technologies and Bductation

Journal of the Faculty of Technics and Technologies, Trakia University https://sites.google.com/a/trakia-uni.bg/artte/

season: clothes were wrapped to the side or fastened on one side, necklines slanted sideways, tucks and seams spiraled around the body. Skirt lengths were no surprise in 1950. They had been creeping up to mid-calf length ever since the two first Collections, and were now about 14 inches from the ground. [6]

\section{OVAL AND LONG LINE}

The Oval line that Dior launched in the spring of 1951 was a masterpiece of dressmaking. There were no gimmicks, just superbly constructed, flattering, womanly clothes. Every edge was rounded: suits hugged the body closely; shoulders simply smoothed into sleeves without a break, and hips and breasts were gently molded. Sleeves seemed to be carved out of cloth and curved at the top; collars were hardly noticeable any more - in fact, Dior often used a simple mandarin neck-band - and jackets were rounded off at the front. As always in a Dior Collection, there were hints of the future as well as echoes of past shows. That spring, he introduced a new, snug bolero jacket that was so short it stopped just below the bust. It was to become the big news for autumn.

Dior used to say that, of all the clothes he had ever designed, those he created for autumn 1951 were the ones he loved best. He called that collection the Long line, but like the Corolle Collection, which almost immediately became known as the New Look, the Long line was soon christened the Princess line - and that is how it will always be remembered. Dior had done something extraordinary: in fact, for the Princess line, the waist actually stayed where it was, but was not emphasizes by a belt. Instead, the illusion of a high waist was given by marking another line just below the bust. This was done by putting short bolero jackets, in contrasting fabrics or colors, over dresses, or by placing a seam under the bust from which gathers rose over the bosom, or by attaching a half-belt high up across the back of a jacket line to the hem. Skirts were fractionally longer to emphasize this long line; they were now 13 to 14 inches from the floor, but looked longer still because of the illusion of a higher waist. [6]

\section{SINUOUS AND PROFILE LINE}

For spring 1952 he launched what he called the Sinuous line: soft, fluid clothes that moved with the body, made no exaggerations and looked timeless and effortless. Of all Dior's Collections, the Sinuous line looks the most modern now. The sweater look consisted of a three-piece outfit: a soft cardigan jacket, a simple little top (sometimes worn outside the skirt to give more of a sweater feeling) and gentle skirt. Dior produced these in all kinds of fabrics but most successfully in soft crépe and in pastel colors.

The casual look of the Sinuous line was a tremendous success, but while other designers took it up for autumn, Dior changed his tune and presented the Profile line. As its name suggests, this line was sharper and more defined: there were still no 'fashion fripperies' and, in fact, the clothes were simpler than ever - stark, even - and cut to outline the body in a dramatic way. Dior's favorite color was black, and he invented a striking new skirt, cunningly constructed to jut out over the hips. Skirts were a little longer - about $11 \frac{1}{2}$ inches from the ground. The hottest news for evening wear, that season, was the little black dress. [6]

\section{TULIP AND CUPOLA}

In 1953 Dior brought back the kind of complicated, precision construction that had made him famous. [7]

The Tulip line was a combination of the Profile line of the previous season and Dior's favorite Princess line. The clothes molded the body from the hem to just under the bust and from there, by means of padding, puffed sleeves or off-the-shoulder necklines, the width of the

IRTIIE Vol. 7, No. 3, 2019 ISSN 1314-8788 (print), ISSN 1314-8796 (online), doi: 10.15547/artte.2019.03.002 


\section{ART'TlE $Y^{2}$}

Ipplied Resseirlores in Technics, Technologies and Bductation

Journal of the Faculty of Technics and Technologies, Trakia University https://sites.google.com/a/trakia-uni.bg/artte/

bust and shoulders was emphasized. Waists were shaped in but not marked with belts or even seams. All in all it was a curvy, feminine, young Collection with no unpleasant surprises: Dior saved these for later.

Dior called his Autumn Collection the Cupola, or Dome, line: there were wide, barrel-shaped coats and jackets with exaggeratedly round shoulders, some delicious dresses with full busts and bell skirts, and a new, rounded 'bustle' back for evening dresses, both short and long. But the beltless, high-waisted Princess dresses held their own too, with waists less marked than ever before. He raised the hemline by two inches to 16 or 17 inches above the ground, or, working the other way, to only a couple of inches below the knee. [6]

\section{LILY OF THE VALLEY AND H LINE}

Dior's Spring Collection was delicious. He called it his Lily of the Valley line. There were relaxed little suits with pleated skirts and short, sailor-collared jackets or bloused battledress tops. There were crisp coats with double-breasted fronts and deep vents at the back. The waist was less emphasized than ever before.

Audience had been charmed by the Lily of the Valley line, but in July, when Dior showed his $\mathrm{H}$ line Collection for autumn, controversy raged around the house once again. Dior's aim with the $\mathrm{H}$ line was to suggest 'the tapering figure of a young girl', by stretching the body out a little and elongating the distance between bosom and hips. He pushed the bust up as high as possible and dropped the waist down to the hips (this line made the cross-bar of the $\mathrm{H}$ ). [6]

\section{A LINE AND Y LINE}

Dior developed the $\mathrm{H}$ line into the $\mathrm{A}$ line - a look that was to be more successful and influential. He narrowed the shoulders and made dresses, coats and suits flare out like triangles, with the waists - the cross-bar of the letter A - up under the bust or low on the hips. Dior's A line represented everything he was best at: a strong theme - but one that made women look feminine and pretty - and one that could be copied fairly easily and still look right. Everyone loved it: "The most wanted silhouette in Paris," Vogue called it, adding wittily, "The prettiest triangle since Pythagoras." The A line and its predecessor, the $\mathrm{H}$ line, were revolutionary. They marked a complete U-turn in fashion, away from the nipped-in waists and full skirts of the New Look to a sleeker, almost waistless shape that, in turn, opened the door to the sack and the shift.

For his autumn Collection that year, Dior went to the alphabet again, skipping from the first letter, $A$, to the second last, $Y$. The $Y$ line was less easy to pinpoint than the $A$, but basically it was defined as a slender body with a top-heavy look. This Dior achieved by adding big collars that opened up in a V shape, like the arms of the $\mathrm{Y}$, with giant stoles swathed about the shoulders or with cropped bolero jackets topping ultra-slim dresses. The $Y$ could be upside down too: long tunics with deep slits up the sides. These were so waistless and easy that they were really early sacks or shifts. [6]

\section{ARROW AND AIMANT}

Like so many of Dior's Spring Collections, this one radiated gentle prettiness rather than revolution. He called the Collection the Arrow line, and showed two new versions of the high waist that he had loved since his Princesse line. This time, there were what he called 'Caraco' jackets, chopped off above the waist to show the belt of the dress underneath, and young and jaunty in spirit. The other, more womanly, look had loose cut jackets caught in with a belt or sash well above the waist and worn over slim skirts. He still liked the straight, side-slit tunic dresses that he had shown the previous autumn, but only for evening. It was

IRTIIE Vol. 7, No. 3, 2019 ISSN 1314-8788 (print), ISSN 1314-8796 (online), doi: 10.15547/artte.2019.03.002 
almost as if he was marking time with this revolutionary idea until the moment was ripe to launch in properly: that moment came in time for his last Collection.

The private man gave way to the showman in the Autumn Collection. The man who had lengthened hems to the ankle in 1947, and then shortened them to below the knee in 1953, now abruptly produced daytime suits with skirts as long as those of an Edwardian lady. The new line was called Aimant, or Loving, and the clothes were romantic in feeling and full off nostalgia for a past age. 'The look that harks back to the epoch of Poiret and Proust,' Vogue called it. Apart from the long hems, Dior swaddled his mannequins in capes of all lengths, cocooned them in cape coats, wrapped them in fur, shadowed their pretty faces with hat veils and put them into the most fragile and delicate evening dresses imaginable.

Vogue explained that if fashion were to accept the Edwardian look of capes and fur stoles and widely-rounded shoulders, then it must also see that 'the silhouette cries out for the balance of a lengthened, narrow skirt.' [6]

\section{LIBRE AND FUSEU}

Dior's Collection that spring was called Libre, or Free, and so it was. Ten years had brought him to the exact opposite of the New Look, with its waist-cinching, padded, structured and elaborately feminine clothes. In fact, Dior based much of his Libre line on two classic items of clothing normally worn by men. One was the vareuse, or fisherman's smock, worn by Breton seamen and which traditionally has a stand-away collar and is cut to hang loosely down to the hips; the other was the khaki bush jacket with its buttoned-down flap pockets. He called his versions of the bush shirt les Sahariennes and made them super-elegant in rich raw silk or natural shantung. The vareuse he translated in all sort of ways - most spectacularly he cut it in leopard skin and put it over a tweed skirt. Skirt lengths for day dropped a couple of inches, and the demi-longueur that had caused all the fuss the year before was now the popular length for cocktail and dinner dresses.

Dior's last Collection was for autumn 1957. He called it the Fuseau, or Spindle, line. No one know, of course, that this was to be the great designer's finale. But Fate was kind, and allowed him to go out on a Collection as revolutionary as the one he had come in with. That autumn, he finally put his seal of approval on the loose chemise shape which had fascinated him for several seasons. This unfitted dress came to be known by many names - the chemise, the chemmy, the tube, the sack, the shift. Like so many of Dior's new ideas, it attracted vociferous critics. They described it as baggy and inelegant, but by September that year French Vogue reported that Dior's battle for the loose line had been won: the proof was that women were wearing it.

The chemise changed our shapes, it altered the whole direction of fashion, and it paved the way for designers like Courréges and Mary Quant and the young, free fashions of the Sixties. [6]

\section{ANALYSIS OF SILHOUETTES OF CHRISTIAN DIOR IN HIS COUTURE COLLECTIONS IN THE PERIOD BETWEEN 1947 AND 1957}

The approach of analysis of Christian Dior silhouettes is approximation in which the form is divided in parts, presented by simple geometric forms.

The geometric properties of costume can be presented by constructing of its structure on the base visual mapping and approximation. The geometry of the form includes indicators of quality and metrics, which allow maximal description of the shape parameters. Albrecht Durer thought that separation in geometric parameters is necessary condition about analysis of one artistic work and its creation. [9] 


\section{ARTITE}

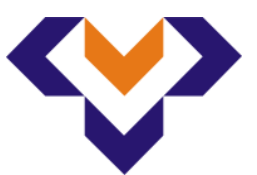

Ipplied Resseirlores in Technics, Technologies and Bductation

Journal of the Faculty of Technics and Technologies, Trakia University https://sites.google.com/a/trakia-uni.bg/artte/

Figures 2, 3, 4 and 5 present approximations of silhouettes of couture collections of Christian Dior for the period from 1947 till 1957. On one and the same body two silhouettes are shown, which are in accordance with both spring and fall collections.

In 1947 the silhouette is "Flower" (Figure 2) with fitting in the waist and dome form of the skirt. The geometrical definition of this silhouette is ellipse, which approximate the upper part over the waist line, and part of ellipse and trapezium for the skirt.

In 1948 "Flower" is the silhouette again (Figure 2), which form is presented in the same way as the line from 1947 - an ellipse for the upper part over the waist line, and part of ellipse and trapezium for the skirt. The bigger volume of the skirt in the costume in 1948, results of its bigger width and height, is the difference.

In 1949 the silhouette is X [10] - optical enlarged upper part and extended down part (Figure 2). The construction of the skirt is similar to the ones from previous two years, but in smaller volume, according to smaller width and height. The upper part of costume is presented with a part of an ellipse and trapezium.

In 1950 the forms of skirts for the both spring and fall collections are rectangular (Figure 3). The upper parts are different $-\mathrm{V}$ form or turned trapezium for spring and an ellipse and $\mathrm{a}$ semi oval for fall silhouette.

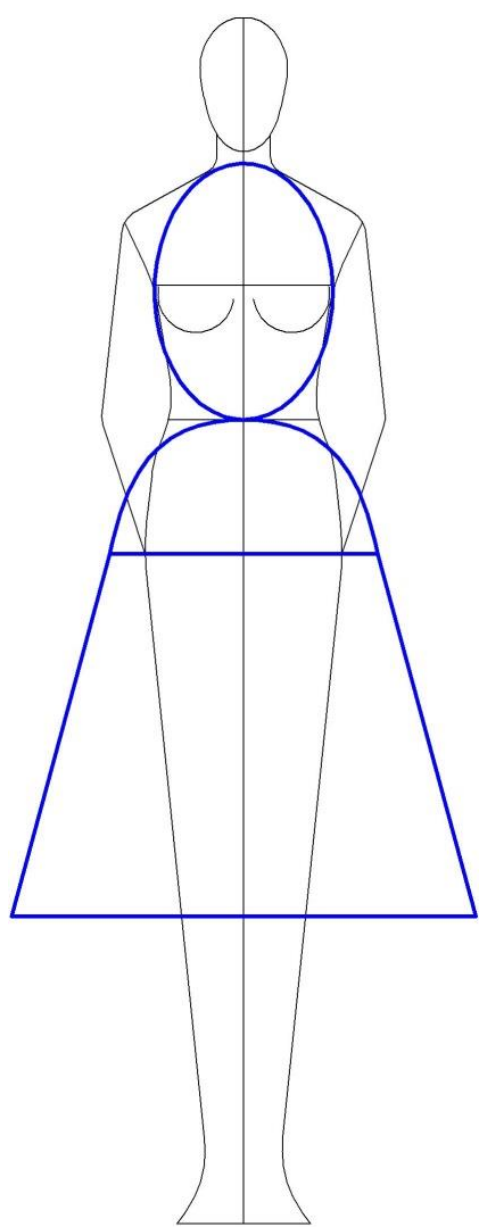

1947

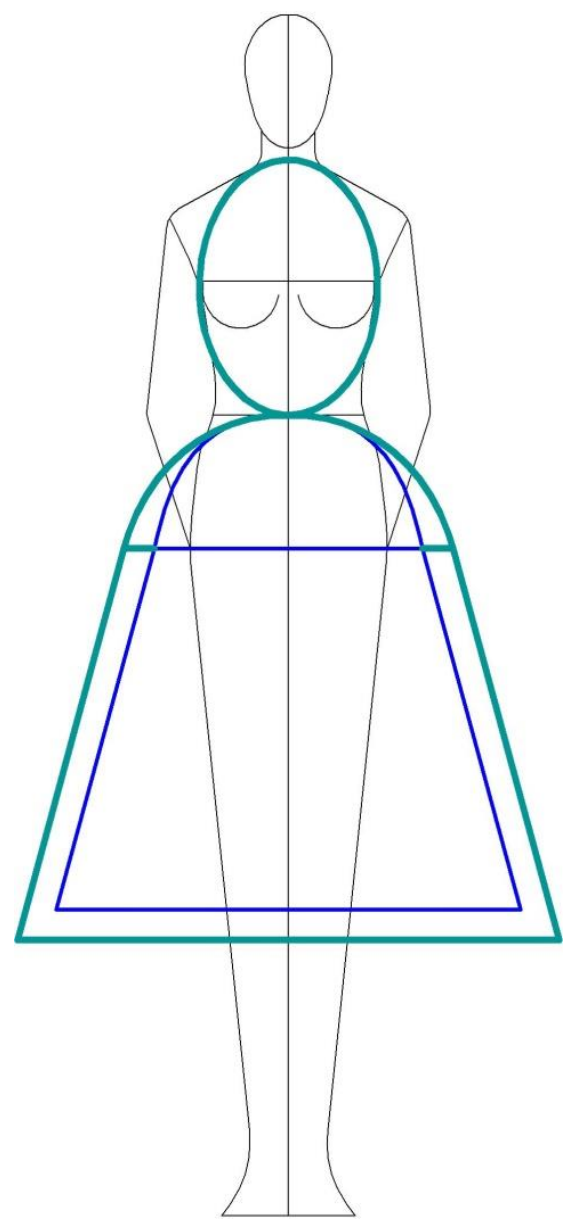

1948

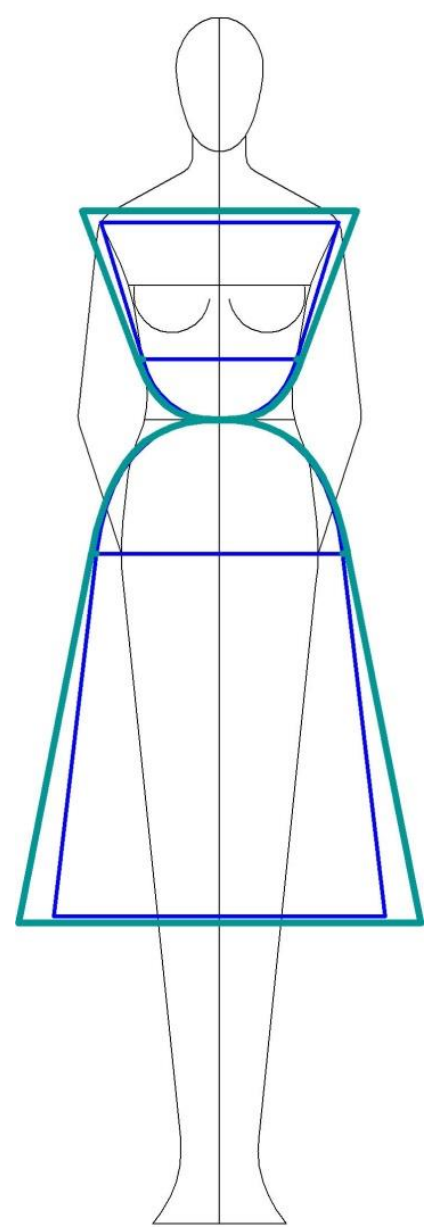

1949

Figure 2. Silhouettes in collections of Christian Dior for 1947, 1948 and 1949, approximated with simple geometric forms 


\section{ARTTIE

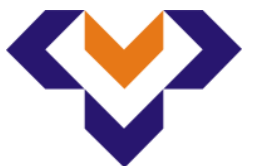 \\ Ipplied Researl'hes in Technics, Technologies and Bdurition \\ Journal of the Faculty of Technics and Technologies, Trakia University https:///ites.google.com/a/trakia-uni.bg/artte/}

In 1951 the spring and fall silhouettes are so different too like 1950 spring and fall lines. In 1951 the silhouette of spring collection (Figure 3) is close fitted one and the silhouette of fall costume is $Y$ turned line [10]. In 1951 the fall line (Figure 3 ) is with high situated waist line and it is presented by a part of an ellipse and a trapezium. The close fitted line of spring costume is shown with an ellipse for the upper part, and a part of an ellipse and a rectangle for the skirt.

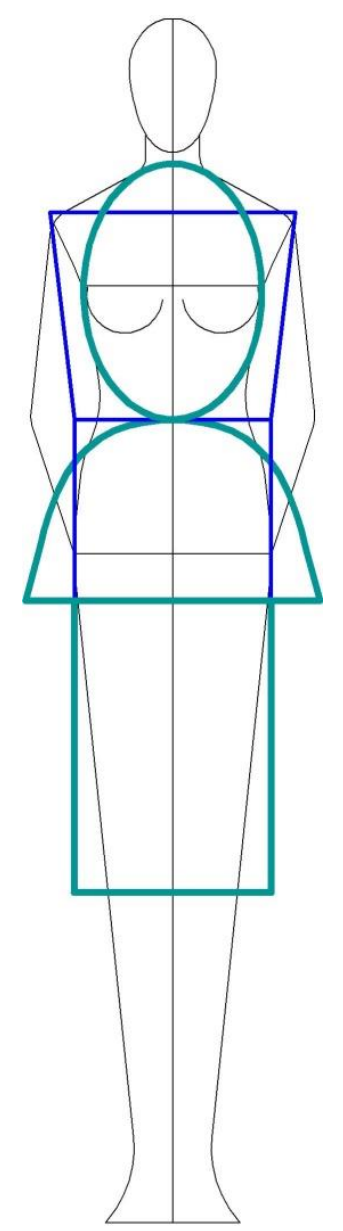

1950

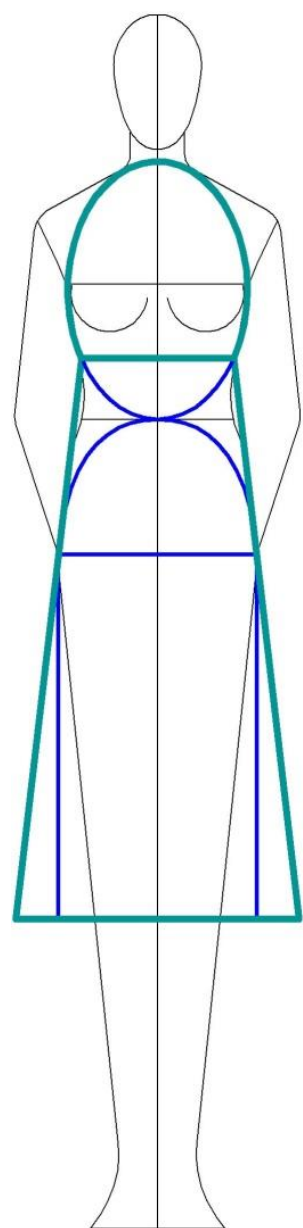

1951

Figure 3. Silhouettes in collections of Christian Dior for 1950 and 1951, approximated with simple geometric forms

In 1952 the spring costume is in $X$ line [10] in clear lines - two trapeziums with common small base in the waist (Figure 4). The fall silhouette is fitted one, very close to the form of the body, presented with an ellipse for the upper part, and a part of an ellipse and a turned trapezium for the skirt (Figure 4).

In 1953 the spring costume is in $Y$ line [10] (Figure 4), in which the shoulders are oval in additional volume and close fitted skirt. The upper part is presented by a part of a circle for the bigger volume shoulders and a part of an ellipse between volume part and the waist. The skirt is shown with a part of an ellipse and a turned trapezium. The fall silhouette is "Flower" (Figure 4), presented by a turned trapezium for upper part, and a part of an ellipse and a trapezium for the skirt.

IRTIIE Vol. 7, No. 3, 2019 ISSN 1314-8788 (print), ISSN 1314-8796 (online), doi: 10.15547/artte.2019.03.002 


\section{IR'ITIE

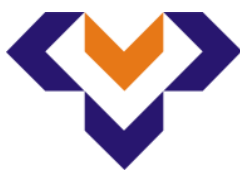

Ipplied Resseirlores in Technics, Technologies and Bductation

Journal of the Faculty of Technics and Technologies, Trakia University https:///ites.google.com/a/trakia-uni.bg/artte/

In 1954 the spring collection silhouette (Figure 4) is the same like the spring collection from 1952. The curved lines are replaced by straight ones and silhouette is presented by two trapeziums. For the fall the silhouette is $\mathrm{H}$ line (Figure 4), presented with a turned trapezium for the upper part and skirt, shown with a trapezium between waist and hip and a turned trapezium, similar to a rectangle between hip and hem.

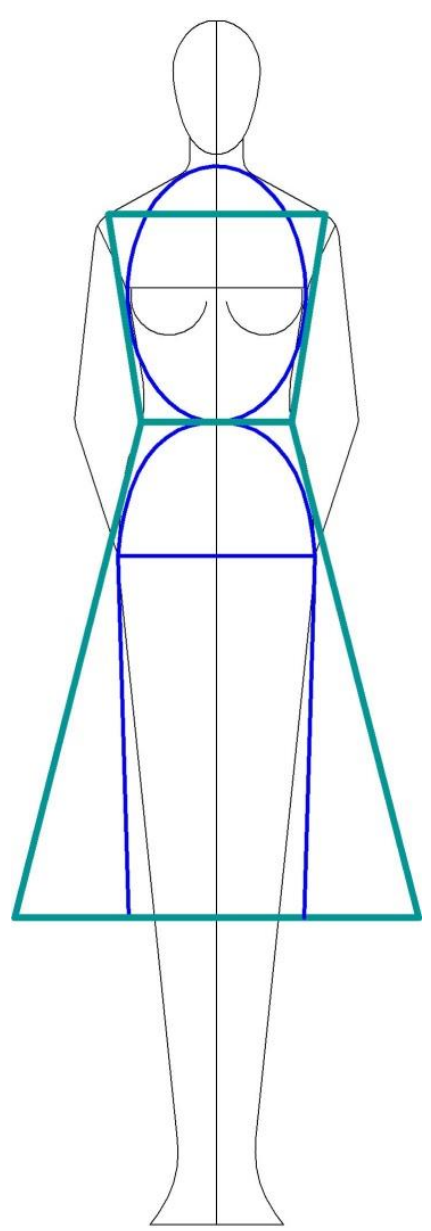

1952

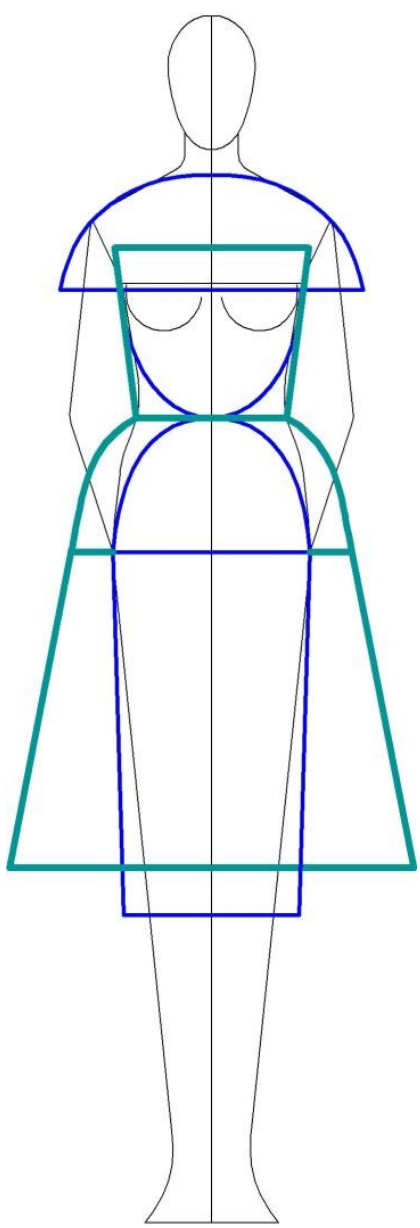

1953

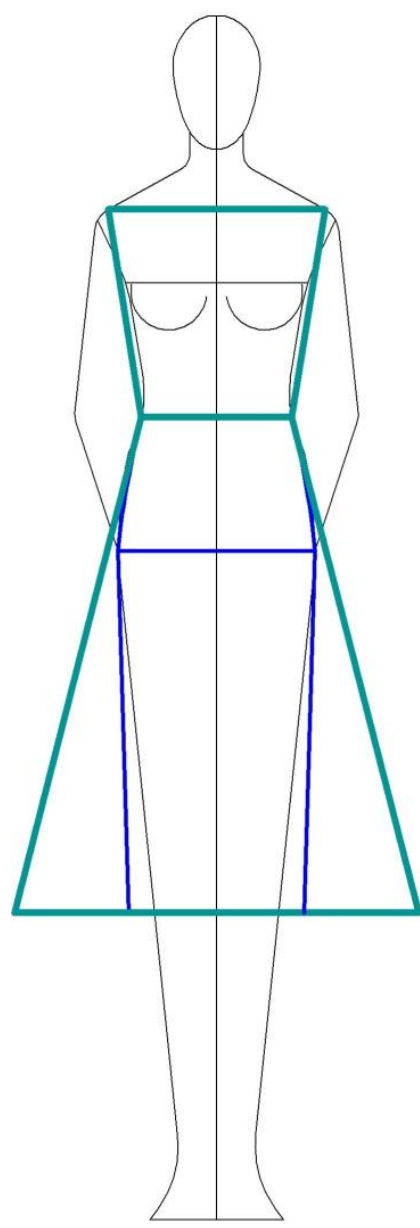

1954

Figure 4. Silhouettes in collections of Christian Dior for 1952, 1953 and 1954, approximated with simple geometric forms

In 1955 the silhouettes are A and $Y$ lines [10] (Figure 5). A line for the spring collection is presented by a rectangle, similar to a square, and a trapezium. $\mathrm{Y}$ line for the fall is presented by two rectangles.

In 1956 the spring silhouette is $Y$ line [10] (Figure 5) and it is similar to the fall one from 1955, but with smaller upper part and it is presented with two rectangles too. In his fall collection Dior developed the line with oval shoulders from 1953. It is O or oval silhouette, presented with a semi ellipse and a rectangle (Figure 5).

In 1957, the last year from the creativity of Christian Dior, the line is simple and straight without or small fitting in the waist and without or small expanding of the skirt, or a silhouette, presented by only one geometric form - one rectangle (Figure 5). 


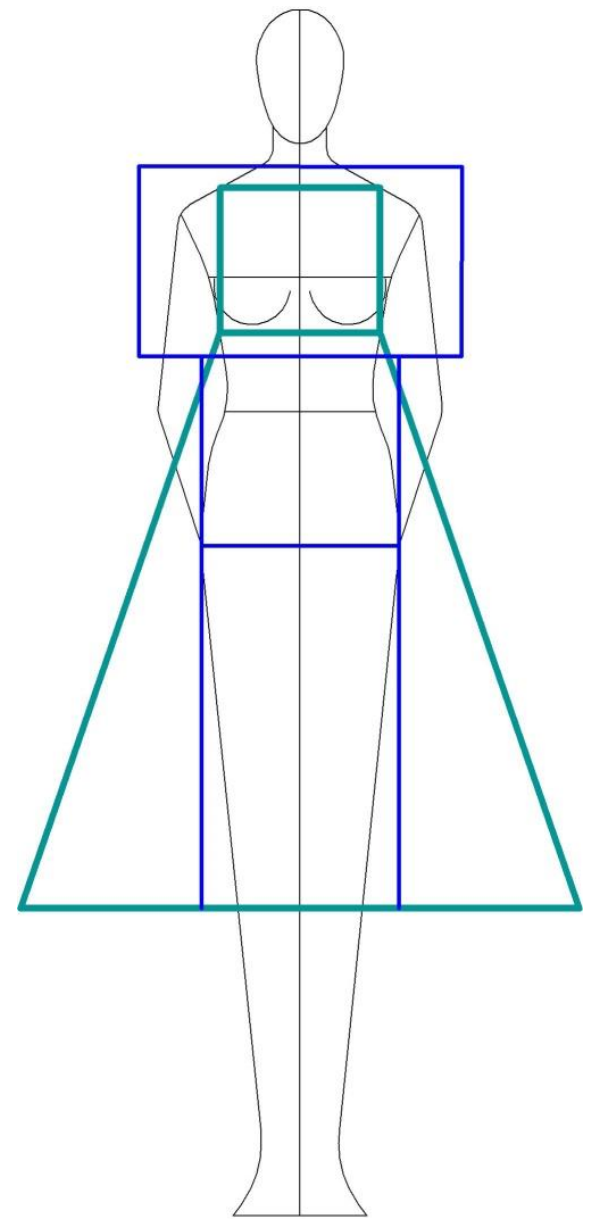

1955

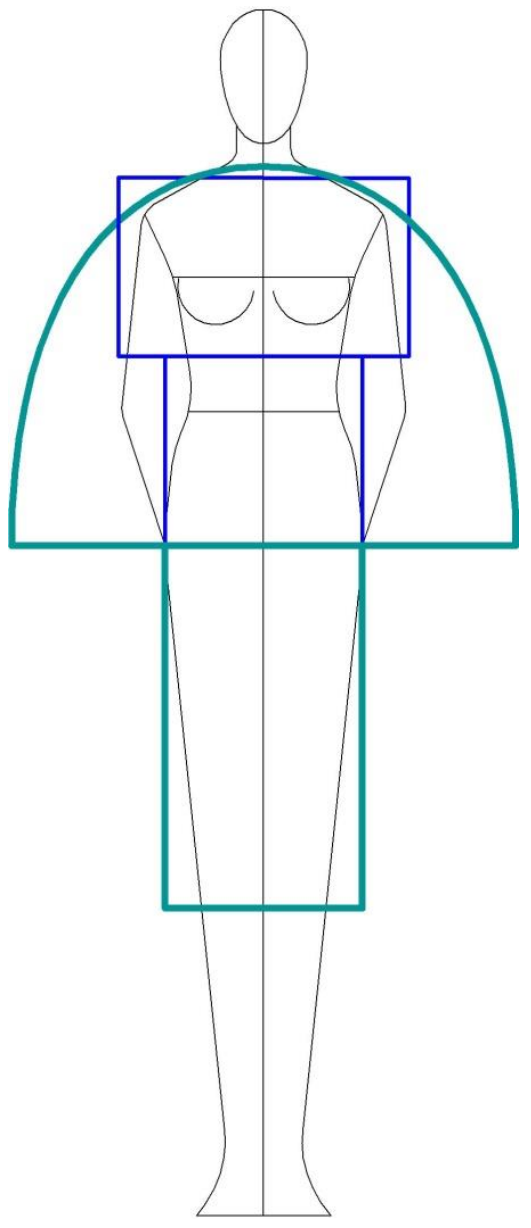

1956

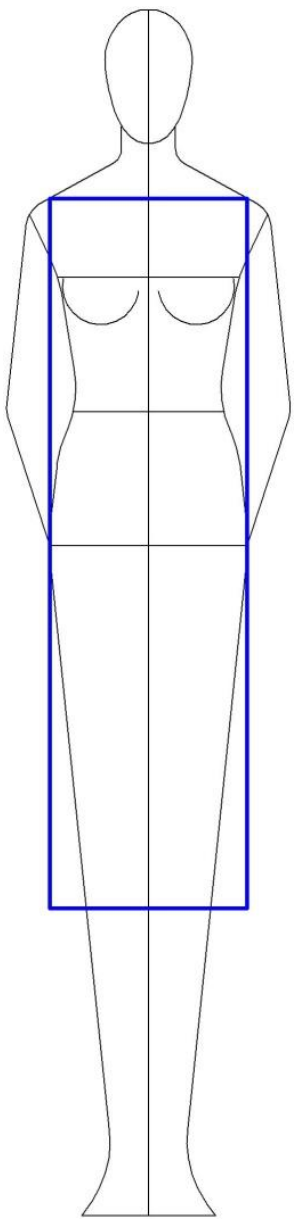

1957

Figure 5. Silhouettes in collections of Christian Dior for 1955, 1956 and 1957, approximated with simple geometric forms

Figure 6 presents the approximations of silhouettes of couture collections of Christian Dior for the period from 1947 till 1957 in the sequence of their creation. It can be seen the development of Christian Dior silhouette forms.
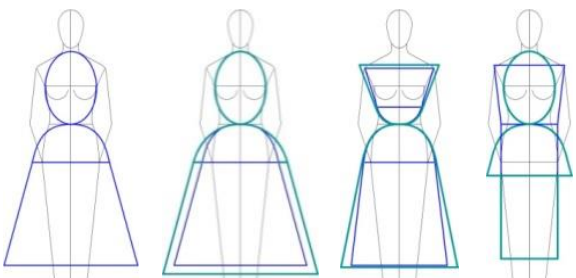

1947

1948
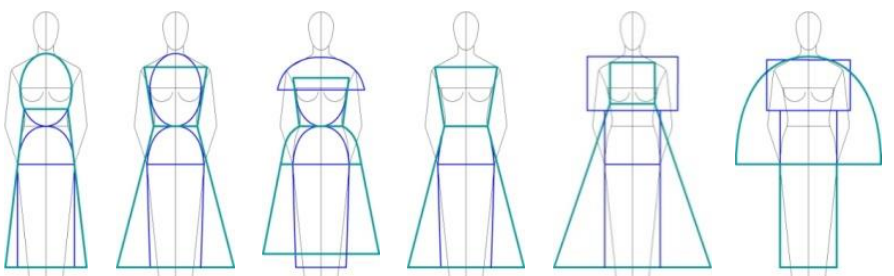

1956

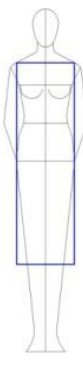

1957

Figure 6. The approximations of silhouettes of couture collections of Christian Dior for the period from 1947 till 1957 in the sequence of their creation

IRTIIE Vol. 7, No. 3, 2019 ISSN 1314-8788 (print), ISSN 1314-8796 (online), doi: 10.15547/artte.2019.03.002 


\section{ARTTIE $Y$}

Ipplied Resseirlores in Technics, Technologies and Bductation

Journal of the Faculty of Technics and Technologies, Trakia University https://sites.google.com/a/trakia-uni.bg/artte/

\section{CONCLUSIONS}

- The costumes of Christian Dior collections for the period between 1947 and 1957 have been created in the silhouettes: "Flower", $\mathrm{X}, \mathrm{Y}, \mathrm{Y}$ turned, $\mathrm{A}, \mathrm{O}, \mathrm{H}$ line, close fitted and rectangular (straight) ones. Christian Dior has created and imposed "Flower", $\mathrm{A}$ and $\mathrm{H}$ line, and he has recreated the other silhouettes giving them new looks.

- By the use of approximation the investigated silhouettes are divided on parts, which visually are similar to simple geometric forms, and after that the silhouettes are presented with combinations between ellipses, ovals, circles, or their parts, trapeziums, and rectangles.

- This way of presentation shows the connection between the forms of costume and human body. The close fitted silhouette or the close fitted parts of silhouettes require more type and number of simple geometric form for approximation.

- The approximated silhouettes for the studied period are complicated combination between curved forms of ellipses, ovals, circles, full figures or their parts, and straight ones of rectangles and trapeziums. The exception is the last Christian Dior collection (fall 1957 ) in which the silhouette is shown by only one rectangle.

- The transition from silhouettes, presented with combination of geometric forms, to the silhouette, shown with only one form, reveals the innovative spirit of Christian Dior and his great influence in the fashion and fashion design.

- The investigation of the silhouettes with the application of approximation with well-known simple geometric forms helps the students in their studies in fashion. The approximated geometric approach helps the activity of fashion designers and pattern makers in their creations of new silhouette forms and their proportions to the human body.

\section{REFERENCES}

[1] Christian Dior: Designer of Dreams. Exhibition ran from 2 February 2019 to 1 September 2019. Victoria and Albert Museum. London, UK, Available: https://www.vam.ac.uk/ [2019-08-23].

[2] Gorina G. (1981). Pattern Design of the Forms of Clothing. Moscow, Light and Food Industry, 1981.

[3] Kaminskaya N. (1977). History of Costume. Moscow, Light Industry, 1977.

[4] Cole D., Deihl N. (2015). The History of Modern Fashion: from 1850. London, UK, Laurence King Publishing Ltd, 2015.

[5] Cullen O., Burks C. K. (2019). Christian Dior. London, UK, V\&A Publishing, 2019.

[6] Keenan B. (1981). Dior in Vogue. London, UK, Octopus Books, 1981.

[7] Hill D. (2007). As Seen in Vogue: a Century of American Fashion in Advertising. Texas, USA, Texas Tech University Press, 2007.

[8] Sinclair Ch. (2015). Vogue on Christian Dior. New York, USA, Abrams, 2015.

[9] Kozlova T. (1988). The base of Theory of Costume Design. Moscow, Light industry and consumer services, 1988.

[10] Kazlacheva Z. (2007). Silhouettes in the Ladies Outer Garments. Tekstil i Okleklo, Vol. 2007, No. 9, pp. 8-11. 